\title{
Die implementering van 'n akwatiese toksisiteitsindeks in die monitering van die Olifantsrivier (Nasionale Krugerwildtuin)
}

\author{
V. Wepener, J.H.J. van Vuren en H.H. du Preez. \\ Navorsingseenheid vir akwatiese en terrestriële ekosisteme. Departement Dierkunde, Randse Afrikaanse Universiteit, Posbus 524, \\ Aucklandpark 2006
}

Die Nasionale Krugerwildtuin (NKW) ontvang water vanaf ses hoofriviere waarvan slegs vier as standhoudend beskou kan word. Die rivier met die grootste opvanggebied en wat die intensiefste benut word, is die Olifantsrivier. Watergebruike in die rivier sluit onder andere mynbou, industriële aktiwiteite, huishoudelike gebruike en landbou in.

Die Departement van Waterwese en Bosbou erken die omgewing as 'n wetlike watergebruiker en dit is dus noodsaaklik dat die bestuur van die NKW op hoogte van die stand van die waterkwaliteit en van die water wat die park binnevloei, bly. Vir die leek is die waterkwaliteitsdata verwarrend en onverstaanbaar, en gevolglik is daar besluit om 'n akwatiese indeks op te stel waarin die waterkwaliteitsveranderlikes opgeneem word. Hierdie veranderlikes word op so 'n manier in die indeks opgeneem dat dit die toksisiteit daarvan op akwatiese organismes (visse) weerspieël. Die akwatiese toksisiteitsindeks is in samewerking met die Departement Toegepaste Wiskunde aan die Randse A frikaanse Universiteit gerekenariseer om die berekening van die indekswaarde te vergemaklik.

Watermonsters van die Olifantsrivier is tweemaandeliks vir die tydperk Februarie 1990 tot Februarie 1992 by verskillende punte binne die NKW versamel. Die fisiese veranderlikes wat bepaal is, sluit pH, opgeloste suurstof en geleiding in. Chemiese veranderlikes soos fluoried, anmonium, fosfate, kalium en totale opgeloste soute is ook bepaal. Die konsen- trasies van swaar metale soos koper, chroom, nikkel, lood, sink en mangaan is deur middel van standaard-atoomabsorpsiespektrofotometriese metodes bepaal. Weefselmonsters van die rooineusonderbek (Labeo rosae) en bloukurper (Oreochromis mossambicus) is by dieselfde moniteringspunte as die watermonsters versamel.

Die weefselmonsters is vir die volgende swaar metale geanaliseer: koper, sink, chroom, lood. mangaan en nikkel. Die waterkwaliteitsveranderlikes is in die rekenaarprogram vervang en 'n finale indekswaarde is vir elke opname bereken.

Uit die resultate blyk dit dat die waterk waliteit vanaf 1990) tot 1992 by al die versamelpunte verbeter het. Dit kan toegeskryf word aan die goeie reënval in Desember 1990 wat die Olifantsrivier in vloed laat kom het. Die vloed het daartoe gelei dat die meeste van die chemiese stowwe stroomaf na Mosambiek gespoel het. Daar is ook gevind dat die vlakke van swaar metale in visweefsel dieselfde tendense as die waterkwaliteit gevolg het.

Met behulp van die akwatiese toksisiteitsindeks behoort die bestuur van die NKW in staat te wees om jaarlikse en sikliese veranderinge op 'n effektiewe en tydbesparende wyse te kan bepaal. Dit stel bestuurders ook in staat om watergebruike in terme van wetlike waterkwaliteitstandaarde te bepaal. Hierdie indeks kan dus op 'n objektiewe manier geïmplementeer word om op 'n herhaalbare wyse, sowel in tyd as in ruimte, varswaterbronne te beheer.

\section{Natuurlike hibridisasie in Pelargonium}

\author{
J.J.A. van der Walt
}

Departement Plantkunde, Universiteit van Stellenbosch, Stellenbosc.'. 7600)

Talle kunsmatige hibriede van Pelargonium is sedert die sewentiende eeu ontwikkel en hierdie hibriede is tans van die populêrste pot- en tuinplante in die wêreld. Die voorouerlike spesies van die kunsmatige hibriede kom almal in Suid-Afrika voor, en dit is hierdie ongeveer 200 natuurlike spesies wat deur 'n navorsingspan by die Universiteit van Stellenbosch, in samewerking met medewerkers in die buiteland, bestudeer word. Die studie is nou in die biosistematiese fase waartydens daar veral op fïlogenetiese verwantskappe gekonsentreer word. Die doel van hierdie ondersoek was om te bepaal of natuurlike hibriede lig werp op die verwantskappe tussen seksies, en ook om te bepaal watter rol hibridisasie tydens spesiasie speel.

Die chromosoomgetalle en -groottes vall die spesies het baie lig gewerp op die oorsprong en identiteit van die natuurlike hibriede. Die volgende somatiese en basiese chromosoomgetalle is in Pelargonium gevind (die getalle wat die meeste voorkom, is kursief):

Somatiese chromosoomgetalle: $2 \mathrm{n}=8,16,18,20.22,32,34,36,38,40,44,58,60,62,84$, 88,104 .

Basiese chromosoomgetalle: $\mathrm{n}=4,7,8,9,10,11,17$. 
TABEL 1

'n Samevatting van die natuurlike hibriede tussen spesies van die verskillende seksies van Pelargonium

\begin{tabular}{|l|ll|c|}
\hline Seksie en basiese chromosoomgetal $(\mathrm{x})$ & & Seksie en basiese chromosoomgetal $(\mathrm{x})$ & Getal hibriede \\
\hline Pelargonium $(\mathrm{x}=11)$ & $\mathrm{X}$ & Pelargonium $(\mathrm{x}=11)$ & 9 \\
Pelargonium $(\mathrm{x}=11)$ & $\mathrm{X}$ & Glaucophyllum $(\mathrm{x}=11)$ & 7 \\
Glaucophyllum $(\mathrm{x}=11)$ & $\mathrm{X}$ & Glaucophyllum $(\mathrm{x}=11)$ & 1 \\
Glaucophyllum $(\mathrm{x}=11)$ & $\mathrm{X}$ & Campylia $(\mathrm{x}=10)$ & 1 \\
Eumorpha $(\mathrm{x}=11)$ & $\mathrm{X}$ & Dibrachya $(\mathrm{x}=11)$ & 1 \\
\hline
\end{tabular}

Totaal 19

Die oorgrote meerderheid van hibriede kom in die seksies Pelargonium en Glaucophyllum Harv. voor wat albei 'n basiese chromosoomgetal van $\mathrm{x}=11$ het. Die chromosome van hierdie twee seksies het dieselfde grootte, maar in vergelyking met dié van sommige ander seksies is hulle relatief klein. Die seksie Campylia (Sweet) DC. met 'n basiese chromosoomgetal van $\mathrm{x}=10$, het ook dieselfde chromosoomgrootte as die seksies Pelargonium en Glaucophyllum. Die chromosome van die seksie Eumorpha (Eckl. \& Zeyh.)Harv. met 'n basiese getal van $\mathrm{x}=11$ is relatief groot, en van dieselfde grootte as dié van seksie Dibrachya (Sweet)Harv. met ' $n$ basiese getal van $x=9$.

Die voorkoms van natuurlike hibriede tussen die seksies
Pelargonium en Glaucophyllum bevestig die vermoede dat hierdie twee seksies naverwant is. Die basiese chromosoomgetal van $\mathrm{x}=10$ word beskou as ' $\mathrm{n}$ afgeleide getal van $\mathrm{x}=11$. Kenmerke van die seksie Campylia dui daarop dat dit uit die seksies Pelargonitum of Glaucophyllum kon ontwikkel het. Die voorkoms van 'n natuurlike hibried tussen spesies van die seksies Glaucophy/lum en Campylia, staaf die vermoede verwantskap tussen die twee seksies. Op grond van verskeie kenmerke word dit tans oorweeg om die seksie Dibrachya oor te plaas na die seksie Eumorpha. Die ontdekking van 'n natuurlike hibried tussen spesies van hierdie seksies bevestig ook die noue verwantskap tussen die twee seksies.

TABEL 2

Getal diploïede en poliploïede spesies in die verskillende seksies van Pelargonium

\begin{tabular}{|l|l|l|l|c|}
\hline Seksie & $\begin{array}{l}\text { Basiese chromo- } \\
\text { soomgetal }(\mathrm{x})\end{array}$ & $\begin{array}{l}\text { Getal diploiede } \\
\text { spesies }\end{array}$ & $\begin{array}{l}\text { Getal poliploiede } \\
\text { spesies }\end{array}$ & $\begin{array}{l}\text { Totale getal } \\
\text { spesies }\end{array}$ \\
\hline Pelargonium & 11 & 12 & 12 & 24 \\
Glaucophyllum & 11 & 6.5 & 0.5 & 7 \\
Polyactium & 11 & 6.5 & 6.5 & 13 \\
Cortusina & 11 & 3 & 2 & 5 \\
Isopetalum & 11 & 1 & 0 & 1 \\
Otidia & 11 & 7 & 1 & 8 \\
Myrrhidium & 11 & 5 & 1 & 6 \\
Ligularia & $8,9,10,11$ & 20 & 8 & 28 \\
Jenkinsonia & 9,11 & 5 & 1 & 6 \\
Peristera & $8,9,11$ & 5 & 1 & 6 \\
Hoarea & $9,10,11$ & 43 & 9 & 52 \\
Ciconium & 9 & 8 & 0 & 9 \\
Dibrachya & 9 & 1 & 1.5 & 1 \\
Eumorpha & $4,8,9,17$ & 4.5 & 2 & 6 \\
Reniformia & 8 & 3 & 46.5 & 177 \\
\hline
\end{tabular}

Uit tabel 2 blyk dit dat die chromosoomgetalle van 177 Pelargonium-spesies bekend is waarvan 130,5 diplö̈ede en 46,5 poliploiede spesies. Dit beteken dat $26,2 \%$ van die spesies poliploiede is. Meiose van ' $n$ hele aantal poliploïede spesies is bestudeer en dit blyk heeltemal normaal te wees. Die poliploïede spesies is verder meesal volkome vrugbaar, en die afleiding kan dus gemaak word dat die meeste allopoliploiede is. Allopoliploiede is egter van hibriede oorsprong en daarom word die gevolgtrekking gemaak dat hibridisasie 'n belangrike rol tydens spesiasie in Pelargonium speel. 


\title{
Die Periplocaceae-genera van Afrika
}

\author{
H.J.T. Venter en R.L. Verhoeven \\ Departement Plantkunde, Universiteit van die Oranje-Vrystaat. Posbus 339, Bloemfontein 9300
}

Sedert Linnaeus die genus Periploca in 1753 bekendgestel het, is minstens nog 86 genera tot op hede vir die Periplocaceae beskryf. As in ag geneem word dat slegs ongeveer 180 spesies in die familie bekend is, is die getal genera in verhouding tot die getal spesies hoog. Agtien van hierdie genera is monotipies.

Alhoewel ' $n$ aantal genera reeds in sinonimie geplaas is, word daar tans nog ongeveer 50 genera vir die familie erken, waarvan 38 in Afrika is. Daar heers egter steeds verwarring by die onderskeiding van hierdie genera. Hierdie verwarring word hoofsaaklik deur die volgende redes veroorsaak. Eerstens is die bou van die blomme van die Periplocaceae besonder ingewikkeld as gevolg van aanpassings by dierbestuiwing; die verskeidenheid blombouvorme dui op 'n groot verskeidenheid bestuiwers. Tweedens is daar tot op hede geen omvattende studie van die hele Periplocaceae uitgevoer nie. Daar is slegs op landstreekbasis ondersoeke vir byvoorbeeld Tropiese Afrika, Suider-Afrika, Tropies Wes-Afrika. Indië, Sjina, ens, uitgevoer. Daar bestaan tans geen volledige sleutel tot die genera van die Periplocaceae nie. Alhoewel so 'n sleutel vir die genera van Afrika bestaan, sluit dit foutiewe genera in. Die onderskeiding van die Afrika-genera word verder bemoeilik omdat dit in samehang met die van veral Madagaskar, maar ook met die van Asië en Australasië beskou moet word.

Die doel van hierdie ondersoek is die bepaling van eienskappe waarop genera afgebaken kan word, en om sinonieme onder die genera van Afrika uit te wys. Die ondersoek is hoofsaaklik op herbariummateriaal afkomstig uit verskeie herbariums van Afrika en Europa uitgevoer.

Die ondersoek dui op 'n aantal bruikbare onderskeidingseienskappe vir uitkenning van genera. Dit kan in twee groepe verdeel word, naamlik 'n konstante groep en 'n minder konstante groep. As konstante eienskappe word beskou: kroonbuisvorm (vlak en pieringvormig teenoor diep en buis- of klokvormig). lengte van kroonbuis en kroonlobbe ten opsigte van mekaar, blootstelling van die ginostegium (versmelte stempelsky fen helmknoppe), posisie van die bykroon op die kroonbuis, getal bykroonkranse, posisie van die meeldrade ten opsigte van die bykroon, harigheid van helmknoppe, klieragtige kolle op die kroonlobbe, teenwoordigheid van intermeeldraadse skyfies en blomknopvorm. Die minder konstante eienskappe is: grootte en tipe bloeiwyse, blomgrootte. helmknopvorm, vergroeiing van bykroonlobbe met mekaar en met die meeldrade, vorm van die stuifmeeldraer, vorm van die stempelskyf, vrugvorm en -tekstuur, vegetatiewe voorkoms, blaarbou en die voorkoms van 'n wortelknol. Stuifmeelbou is deur die familie relatief eenvormig en minder benutbaar vir onderskeiding van taksa.

Uit die ondersoek blyk dit duidelik dat sekere eienskappe konstant optree en gevolglik hoë waarde vir genusonderskeidings besit. Dit is egter waar dat daar nie starre beginsels vir genusonderskeidings neergelê kan word nie. In elke geval moet die gesamentlike voorkoms vall eienskappe vir finale afbakening in oorweging geneem word. In een genus kan 'n minder bruikbare eienskap konstant voorkom en dus sterk onderskeidend wees. dog in 'n ander geval kan dieselfde eienskap waardeloos wees. Op grond van bogenoemde studie is dit reeds duidelik dat Pentagonanthus Bullock en Triodoglossam Bullock in Raphionacme Harv. moet versink. Tacazzea Decne. sal waarskynlik in Streptocaulon Wight \& Arn., 'n genus van Asië, versink en Curroria Planch. in Cryptolepis $\mathrm{R}$. Br.

\section{Niestyselpolisaggariede en glukemiese indekse van verskillende kultivars geblikte droëbone}

\author{
A. Verster, A. Theunissen, H. Scoltz, I. van den Berg, C.S. Venter, H.H. Vorster, J. Jerling en W. Oosthuizen \\ Voedingsnavorsingsgroep, Potchefstroomse Universiteit vir CHO, Potchefstroom 2520
}

Die hipotese dat oplosbare niestyselpolisakkariede (NSP) belangrike bepalers van die glukemiese indeks (GI) van droëbone Phaseolus vulgaris is, is getoets. Tydens die eerste fase van die studie is totale, onoplosbare en oplosbare NSPwaardes van sewe kultivars klein, wit droëbone met die Englyst-ensiematieskolorimetriese metode bepaal. Hierdie sewe kultivars is op drie verskillende lokaliteite in SuidAfrika (Potchefstroom, Delmas en Bethlehem) gekweek. Tydens die tweede fase van die studie is die Gl van drie van hierdie kultivars, gekweek te Delmas en in tamatiesous geblik, bepaal. 'n Homogene groep van ses gesonde dames het volgens 'n Latynse blokontwerp aan die studie deelgeneem. Die refensiemaaltyd het vir $50 \mathrm{~g}$ glukose bestaan. Bygevoegde suiker het $36,3 \%$, tamatiesous $8.27 \%$ en die bone het $55,5 \%$ tot die 50 g-koolhidraatlading van die droëbonemaaltyd bygedra. Die resultate het getoon dat die totale NSP-waardes van die kultivars tussen 1.5 en $38,4 \%$ gewissel het, hoofsaaklik as gevolg van die verskille in onoplosbare NSP-inhoude. Die totale NSP van 'n spesifieke kultivar, gekweek in verskillende lokaliteite, het tot soveel as $36 \%$ gevarieer. Die GI van die drie getoetste kultivars was $55,57 \%$ en $28 \%$ respektiewelik. Daar is geen korrelasie tussen die Gl en oplosbare NSP-inhoud gevind nie. Die gevolgtrekking kan gemaak word dat sowel kultivar as lokaliteit die NSP-inhoud van droëbone beïnvloed en dat ander faktore soos tipe stysel, styselproteieninteraksies en teenwoordigheid vall antinutriënte moontlik 'n groter invloed op die GI van droëbone het as die NSP-inhoud. 


\title{
Kwaliteitskontroles vir die bepaling van endotoksiene in ' $n$ in vitro-bevrugtingsprogram
}

\author{
C. Huyser en F. le R. Fourie
}

Sentrum vir Fertiliteitstudies, Departement Obstetrie en Ginekologie, Universiteit van Pretoria, Pretoria 0002

Die oorsaak van verlaagde kliniese swangerskappe tydens in vitro-bevrugting (IVB) gedurende Januarie - Maart 1989 is toegeskryf aan die voorkoms van endotoksiene in kultuurmediumpoeier. Die doeltreffendheid en sensitiwiteit van toetse vir endotoksiene is bevraagteken en verder in hierdie studie ondersoek.

Die volgende eksperimente is uitgevoer:

Eksperiment 1: Vertrouenslimiete (95\%) vir muisembrioontwikkeling in EBSS is bepaal $(\mathrm{n}=1026)$.

Eksperiment 2: EBSS is met endotoksiene ( $E$. coli) gesupplementeer $(0,025-20,0 \mathrm{ng} / \mathrm{ml})$ en muisembrio-ontwikkeling in hierdie medium is met ' $n$ kontrole vergelyk.

Eksperiment 3: Die teenwoordigheid van endotoksiene in gesupplementeerde medium is met die Limulus Amebosiet Lisaat (LAL)-stollingstoets bevestig.

Eksperiment 4: 'n Minitan-ultrafiltreringsisteem (molekulêre diskriminasie $>10000$ daltons) is gebruik om endo- toksiengesupplementeerde medium te suiwer. Die gesuiwerde medium is d.m.v. muisembrio-ontwikkeling, LALen spektrofotometriese analises getoets.

Eksperiment 5: 'n Vergelyking tussen 'n chromogeniese en gel LAL-toets vir endotoksienopsporing is uitgevoer. Mediums en materiale van vier IVB-laboratoriums is ook getoets.

Daar kan tot die gevolgtrekking gekom word dat die muisembriomodel nie ' $n$ betroubare sisteem is om endotoksiene in kultuurmedium op te spoor nie. Die chromogeniese LAL-toets blyk meer sensitief te wees as die gel LAL-toets vir die opsporing van endotoksiene. Die Minitan-ultrafiltreringsisteem blyk effektief te wees om endotoksicne te verwyder, maar is onprakties vir daaglikse gebruik in 'n IVBeenheid. Alternatiewe kwaliteitskontroles om die teenwoordigheid van endotoksiene op te spoor, word tans ondersoek.

\section{Swangerskapuitkoms na in vitro-bevrugting by die Reproduktiewe Biologienavorsingseenheid 1983 - 1991}

A. Koch, F. le R. Fourie, C. Huyser, I. Nel en C.J. Meintjes

Sentrum vir Fertiliteitstudies, Departement Obstetrie en Ginekologie, Universiteit van Pretoria, Pretoria 0002

'n Retrospektiewe studie is uitgevoer om die swangerskapuitkoms van in vitro-bevrugtingspasiënte by die eenheid te bepaal. Vanaf Oktober 1983 tot Desember 1991 is 1643 pasiënte geaspireer waarvan $82,5 \%$ 'n daaropvolgende embrioterugplasing (ET) gehad het. Dit het aanleiding gegee tot 'n gemiddelde swangerskapsyfer van $20,4 \%$ en 'n geboortesyfer van $10,7 \%$ per ET. Geen statisties betekenisvolle verskil in swangerskappe, aborsies of geboortes kon waargeneem word tussen die eerste vier IVB-pogings nie. 'n Merkbare toename in swangerskappe is waargeneem namate meer embrio's per poging ( tot ' $n$ maksimum van vier embrio's) teruggeplaas is. Sowel optimale swangerskppe $(33,8 \%)$ as geboortes $(17,4 \%)$ het voorgekom wanneer 4 embrio's teruggeplaas is.

Die gemiddelde fetale ouderdom van die enkelinge was 258 dae in vergelyking met 245 dae by die meerlinge. Hierdie verskil kan moontlik toegeskryf word aan die willekeurige, premature ingreep van die verloskundige in die geval van 'n meerlingswangerskap. Die verhouding van seuns tot dogters was 1:0,951. Die hoë aborsiesyfer $(41,5 \%)$ wat gepaardgaan met IVB word weer deur hierdie studie weerspieël. Oorsake en behandeling daarvan behoort verder ondersoek te word.

\section{$\alpha_{1}$-antitripsien, plasminogeen, totale proteiene en gonadotropien in follikulêre vog tydens in vitro-bevrugting (IVB): 'n loodsstudie}

P. Levay, C. Huyser en F. le R. Fourie

Sentrum vir Fertiliteitstudies, Departement Obstetrie en Ginekologie, Universiteit van Pretoria, Pretoria 0002

M. Viljoen

Departement Fisiologie, Universiteit van Pretoria, Pretoria 0002

Die doel van hierdie loodsstudie was om die moontlike verband tussen $\alpha_{1}$-antitripsien (AA), plasminogeen (PM), totale proteïne, gonadotropien (FSH en $\mathrm{LH}$ ) en volume in follikulêre $\operatorname{vog}(\mathrm{FV})(\mathrm{n}=47)$ van 44 in vitro-bevrugtingpasiënte te ondersoek. Groepe is ingedeel in a) klinies swanger pasiënte (PP) met 'n volume $\geq 4 \mathrm{ml}$ en $<4 \mathrm{ml}(\mathrm{n}=$
13), b) nieswanger pasiënte (NPP) met 'n volume $\geq 4 \mathrm{ml}$ en $<4 \mathrm{ml}(\mathrm{n}=16)$, c) follikulêre vog sonder oösiete ( $\mathrm{SO})(\mathrm{n}=$ 11) en d) follikulêre vog van pasiënte wat ge-ovuleer het gedurende aspirasie (OV) $(n=7)$.

Resultate toon aan dat:

a) LH-vlakke betekenisvol hoër $(p=0,0032)$ en die FSH/ 
LH-verhouding betekenisvol laer is $(p=0,0141)$ in die PPgroep $(\bar{x}=14,01 \mathrm{mIU} / \mathrm{ml}$ en $\bar{x}=0,467$ respektiewelik) in vergelyking met die NPP-groep $(\bar{x}=8,68 \mathrm{mIU} / \mathrm{ml}$ en $\overline{\mathrm{x}}=$ 0,763 respektiewelik);

b) proteïenkonsentrasies betekenisvol hoër $(\mathrm{p}<0,01)$ in die PP-groep (volume $\geq 4 \mathrm{ml})(\bar{x}=61,71 \mathrm{mg} / \mathrm{ml})$ en die NPPgroepe is (volume $<4 \mathrm{ml}$ en $\geq 4 \mathrm{ml})(\overline{\mathrm{x}}=61,30$ en $\overline{\mathrm{x}}=61,24$ onderskeidelik) in vergelyking met die SO-groep $(\bar{x}=54,94)$;

c) plasminogeenkonsentrasie betekenisvol hoër ( $\mathrm{p}<$ $0,05)$ in die PP-groep met volumes $\geq 4 \mathrm{ml}$ is $(\overline{\mathrm{x}}=0.095 \mathrm{mg} /$ $\mathrm{ml})$ in vergelyking mel volumes $<4 \mathrm{ml}(\overline{\mathrm{x}}=0,(073 \mathrm{mg} / \mathrm{ml})$, wat daar op dui dat plasminogeen verhoog met follikelgrootte in swanger pasiënte.

Die gevolgtrekking is gemaak dat verhoogde plasminogeenkonsentrasies met groter (dus ryper) follikels geassosieerd is in FV van swanger pasiënte. LH kan moontlik aanduidend wees van swangerskapuitkoms in IVB-pasiënte. Toekomstige analises sal breedvoeriger uitgevoer word sodat die verband tussen FSH en LH-konsentrasies in FV en swangerskapuitkoms in IVB-pasiënte ondersoek kan word.

\title{
Biochemiese profiel van menslike follikulêre vog tydens in vitro- bevrugting (IVB) versamel
}

\author{
C. Huyser, F. le R. Fourie en P. Levay \\ Sentrum vir Fertiliteitstudies, Departement Obstetrie en Ginekologie, Universiteit van Pretoria, Pretoria (0002
}

Follikulêre vog (FV) dien as kultuurmedium vir die oösietcorona-cumuluskompleks (OCCK) en reflekteer dus maturiteitsveranderinge van die OCCK. Die doel van hierdie studie was om: a) bloedgekontamineerde FV te elimineer; b) die biochemiese milieu van die follikel te bepaal en $c$ ) moontlike merkers in helder FV te identifiseer wat van prognostiese waarde kan wees vir'n suksesvolle IVB-poging.

'n Totaal van 236 vroulike pasiënte wat oösietherwinning in in vitro-bevrugting ondergaan, is ingesluit in hierdie studie. Onmiddellik nadat die oösiet geidentifiseer is, is die vog ( $\mathrm{n}$ = 596) gesentrifugeer en spektrofotometries geanaliseer vir die teenwoordigheid van bloed. Bloedkontaminasie is by $28,6 \%$ van die vog gevind wat daarna uitgesluit is vir analise. Die oorblywende vog (wat geen bloed bevat het nie) is verdeel in kleiner hoeveelhede en by $-70{ }^{\circ} \mathrm{C}$ geberg tot verdere gebruik. Die veranderlikes wat bepaal is, is $\mathrm{LH}$, FSH, PRL, menslike chorioniese gonadotropien (mCG), sialiensuur, testosteroon (T), melatonien, elektroforeto- gramme, $\alpha_{1}$-antitripsien, plasminogeen en totale proteiene.

Die gemiddelde volume van geaspireerde $F V$ is $4,4 \pm 2,3$ $\mathrm{ml}$ met ' $\mathrm{n}$ reikwydte van 1,0 tot $15,0 \mathrm{ml}$. Prolaktienkonsentrasie was die enigste veranderlike wat betekenisvol verskil het by FV met of sonder 'n oösiet $(p=0,0056)$. Volgens die resultate blyk dit dat laer FSH-konsentrasies, maksimale spektrale absorbansies by $458 \mathrm{~nm}$, sowel as hoër $\mathrm{mCG}$ konsentrasies met kleiner follikels $(<3,() \mathrm{ml})$, in vergelyking met groter follikels $(\geq 6,0 \mathrm{ml})$, geassosieer is $(p=0,03)$. Die studie toon verder geen verskille aan tussen die elektroforetiese patrone van follikulêre en serumproteine nie, behalwe vir die teenwoordigheid van fibrinogeen in FV en $\beta$-lipoproteine in serum.

Daar is tot die gevolgtrekking gekom dat FV-proteïene nie goeie voorspellende merkers van IVB-uitkoms is nie. Gonadotropien, prolaktien, ImCG en spektrofotometriese absorbansie daarenteen toon potensiaal as moontlike voorspellers.

\section{Waarnemings by die bobbejaan as model vir in vitro-bevrugting}

\author{
F. le R. Fourie \\ Sentrum vir Fertiliteitstudies, Departement Obstetrie en Ginekologie, Universiteit van Pretoria, Pretoria 0002
}

'n Studie is uitgevoer op die chacma-bobbejaan(Papio ursinus) as 'n moontlike primaatmodel vir in vitro-bevrugting (IVB). Die studie bestaan uit 3 fases:

Fase 1: Waarnemings by 'n bobbejaanmannetjie Agt mannetjies is herhaaldelik geëlektrostimuleer tot ejakulasie vir ' $n$ totalal van 42 pogings met 'n $85,7 \%$ suksessyfer. Die was- en opswemprosedure het ' $n$ betekenisvolle $(\mathrm{p}<$ $0,05)$ toename in motiliteit en getal lewende sperme tot gevolg gehad. Plasmatestosteroonvlakke verminder betekenisvol $(\mathrm{p}<0,05)$ in die winter $(23,4 \pm 12,6$ vs $19,2 \pm 6,8$ nmol.L) teenoor die somer.

Fase 2: Super-ovulasie en in vitro-bevrugting Tien bobbejaanwyfies is gebruik vir 20 gestimuleerde siklusse. Drie ovulasie-induksiemetodes is gebruik: a) clomifeensitraat, b) clomifeensitraat en swangermerrieserum, c) menslike menopousale gonadotropien (mMG). 'n Gemiddeld van $8,0 \pm 5,4$ oösiete per aspirasie is verkry. Die meeste oösiete $(11,3 \pm 6,7)$ is herwin na toediening van clomifeen/ swangermerrieserum terwyl die beste bevrugtingskoers gevind is met $50 \mathrm{mg}$ clomifeensitraat. Die beste resultate vir oösietverdeling en embrioterugplasing is gevind na toediening van $\mathrm{mMG}(14,8 \%)$.

Fase 3: Invloed van clomifeensitraat op menstruele sikluslengte

Clomifeensitraat verhoog die duur van die menstruele siklus $(p<0,05)$ van 'n normale sikluslengte van $36,8 \pm 6,3$ dae na $46,7 \pm 17,1$ dae. 'n Meegaande verhoging $(p<0,05)$ in die duur van die periniale swelling is waargeneem.

Hierdie studie bevestig dat die bobbejaan nog nie suksesvol tot sy volle potensiaal as 'n IVB-model ontwikkel is nie. 


\title{
Die effek van 'n visoliekonsentraat op die plasmafibrinogeenvlakke in gesonde vrywilligers: 'n dubbelblinde, plasebogekontroleerde oorkruisstudie
}

\author{
W. Oosthuizen, J.C. Jerling, H.H. Vorster, N. Silvis, A. Kruger, J.A. Kellerman en C.S. Venter \\ Voedingsnavorsingsgroep, Potchefstroomse Universiteit vir CHO, Potchefstroom 2520 \\ H.C. Barnard \\ Departement Chemiese Patologie, Mediese Fakulteit, Universiteit van die Oranje-Vrystaat, Posbus 339, Bloemfontein 9300
}

Fibrinogeen is 'n belangrike risikofaktor vir die ontwikkeling van koronêre hartsiektes. Visolie bevat eikosapentanoïese suur(EPS) en dokosaheksanoiese suur(DHS) wat fibrinogeen voordelig mag beïnvloed. Teenstrydige resultate in die literatuur oor hierdie effek sowel as die afwesigheid van bekende meganismes waardeur visolie fibrinogeen mag beïnvloed, het as motivering vir hierdie studie gedien. Twintig gesonde vrywilligers ( 10 mans, 10 vrouens) is ewekansig verdeel om daagliks óf $6 \mathrm{~g}$ visolie $(1,14 \mathrm{~g}$ EPS, $0,44 \mathrm{~g}$ DHS) óf $6 \mathrm{~g}$ olyfolie (plasebo) te ontvang, vir 'n periode van 6 weke. 'n Uitwasperiode van 3 weke het gevolg waarna die behandeling omgeruil is vir 'n verdere 6 weke. Die uitwerking op die volgende parameters is bepaal: serumlipiede, vryvetsure (VVS), insulien, glukose, proteïene, ensieme, uitskeidingsprodukte, minerale, plasmafibrinogeen en rooibloedselmembraan-vervormbaarheid (RBSMV). Visolie het ' $n$ betekenisvolle afname in serumtrigliseriede veroorsaak $(0,70 \pm$ $0,26$ tot $0,53 \pm 0,21 \mathrm{mmol} / \mathrm{L})$. Sowel visolie as olyfolie het die plasmafibrinogeen verlaag, maar dit was slegs betekenisvol in geval van die vrouens $(3,22 \pm 0,91$ tot $2,61 \pm 0,52$ $\mathrm{g} / \mathrm{L}$ en $3,19 \pm 0,72$ tot $2,66 \pm 0,49 \mathrm{~g} / \mathrm{L}$ respektiewelik).

\begin{abstract}
Moontlike redes hiervoor is dat die aanvanklike fibrinogeenwaardes in die vrouens hoër was as in die mans, en dat serumvryvetsure in mans wat olyfolie ontvang het, verhoog het $(0,21 \pm 0,08$ tot $0,30 \pm 0,10 \mathrm{mmol} / \mathrm{L})$. Geen verandering is waargeneem met visolie-inname op hematokrit, RBSMV, liggaamsmassa-indeks, middel-heup-verhouding, serum TC, HDL-C, LDL-C en VVS-vlakke nie. Daar was 'n neiging vir insuliensensitiwiteit om te verlaag in vrouens met die inname van sowel vis- as olyfolie $(243,0 \pm 138,96$ tot $158,12 \pm 53,19$ en $274,47 \pm 95,48$ tot $152,32 \pm 51,47$ respektiewelik). Visolie het moontlik nie oksidatiewe hemolise veroorsaak nie omdat geen veranderinge waargeneem is in hematokrit, serum $\mathrm{Fe}$, bilirubien, ongekonjugeerde bilirubien en laktaatdehidrogenase nie en daar 'n afname in serum Ca was. Daar is tot die gevolgtrekking gekom dat visolie moontlik plasmafibrinogeen kan verlaag in persone met hoë aanvanklike fibrinogeenvlakke. Veranderinge in fibrinogeenvlakke kan nie toegeskryf word aan veranderinge in sirkulerende vryvetsuurvlakke nie. Dit is duidelik dat olyfolie nie 'n geskikte plasebo was in hierdie studie nie, as gevolg van die onafhanklike effekte daarvan.
\end{abstract}

\section{Die invloed van twee dosisse visoliesupplemente op die plasma- fibrinogeenvlakke van die Zuckervetrot}

\author{
J.A. Kellerman, F.J. Veldman, J.C. Jerling, W. Oosthuizen, D.G. van der Nest, H.H. Vorster en C.S. Venter \\ Voedingsnavorsingsgroep, Departement Voeding, Potchefstroomse Universiteit vir CHO, Potchefstroom 2520
}

\begin{abstract}
Verwesterse Suid-Afrikaanse bevolkingsgroepe het almal 'n hoë insidensie van koronêre hartvaatsiektes (KHVS). Die inname van $n-3$ vetsure, wat ryk is aan eikosapentaenoïese suur (EPA), het beskermende effekte teen die ontwikkeling van KHVS deur verskeie effekte op hemostatiese veranderlikes. Fibrinogeen word beskou as 'n risikofaktor en merker vir die ontstaan van aterosklerose. Kontroversie bestaan egter in die literatuur aangaande die effek van visolie (ryk aan EPA) op plasmafibrinogeen. Die Zuckervetrot word beskou as ' $n$ geskikte model om dieet-effekte en meganismes van insulien en fibrinogeen op insuliensensitiwiteit te bestudeer. Die doel van die studie was om die effek van 2 farmakologiese dosisse eikosapentaenoïese suur (EPA) op die plasmafibrinogeenvlakke van die Zuckervetrot te toets. 48 volwasse Zuckervetrotte is ewekansig in 4 groepe verdeel,wat elk saamgestel is uit 4 wyfies en 8 mannetjies. Die kontrolegroep het 'n semisintetiese Westerse dieet ontvang,
\end{abstract}

terwyl die eksperimentele groepe dieselfde dieet gevolg het, gesupplementeer met visolie $(86 \mathrm{mg}$ EPA/kg liggaamsmassa of $172 \mathrm{mg}$ EPA $/ \mathrm{kg}$ liggaamsmassa). Olyfolie is as plasebo gebruik. Supplementering het vir 10 weke plaasgevind. Bloedmonsters is met kardiale punksie verkry nadat die proefdiere narkose toegedien is. Serumlipiede, insulien, glukose, hemoglobien en plasmafibrinogeen is bepaal met behulp van kolorimetriese, ensiematiese en koaguleringsmetodes. Geen betekenisvolle verskille in TC en TG vir beide geslagte is tussen die verskillende ingrepe opgemerk nie. 'n Betekenisvolle verskil in plasmafibrinogeen is opgemerk tussen die wyfie-Zuckervetrotte vir die verskillende ingrepe ( $p<0.05$, Student t-toets). Insuliensensitiwiteit is vir altwee geslagte bereken (IS $=10000 \div$ (insulien $\mathrm{x}$ glukose). ' $n$ Hoogs betekenisvolle afname in IS is vir sowel die mannetjies as die wyfies opgemerk met visoliesupplementering ( $\mathrm{P}<0.01$, Student $t$-toets). 'n Betekenisvolle afname 
in hemoglobien is vir mannetjie- en wyfie-Zuckervetrotte opgemerk. Die verlaging in hemoglobien is moontlik as gevolg van hemolise. Geen betekenisvolle verskille is opgemerk vir die hematokritwaardes van die Zuckervetrotte nie. Daar is bevind dat TG in proefpersone meestal verlaag met EPA-supplementering. Dit was egter nie die geval in die Zuckervetrot nie, moontlik as gevolg van 'n verhoogde insulienweerstand in die obese diabetiese model. 'n Afname in IS lei moontlik na verhoogde librinogeenvlakke. Alhoewel daar ' $n$ hoogs betekenisvolle afname in IS was, het die verwagte toename in plasmafibrinogeen nie plaasgevind nie. Dit is aan 'n moontlike direkte effek van visolie op plasmafibrinogeen toeskryfbaar.

\title{
'n Mikroskoopstudie van die voortplantingstelsel van Perionyx excavatus (Oligochaeta) ten einde voortplantingstrategieë te ondersoek
}

\author{
R. Pieterse en S.A. Viljoen \\ Departement Dierkunde, Potchefstroomse Universiteit vir CHO, Potchefstroom 2520
}

\author{
A.J. Reinecke \\ Departement Soölogie, Universiteit van Stellenbosch, Stellenbosch 7600
}

\begin{abstract}
Perionyx excavatus is 'n tropiese oligogeetspesie wat 'n belangrike rol in die proses van vermikompostering kan speel. Hierdie erdwurmspesie plant onder natuurlike toestande, sover bekend amfimiekties, voort. Daar is egter gevind dat $P$. excavatus onder laboratoriumtoestande, sonder kontak met 'n paringsgenoot, lewensvatbare kokonne produseer. Tydens die huidige studie is gepoog on vas te stel watter voortplantingstrategieë die wurm beoefen ten einde hierdie verskynsel te bewerkstellig.

Selfbevrugting is ' $n$ moontlike strategie, en ten einde hierna ondersoek in te stel, is die uit- en inwendige bou van die geslagsorgane van die wurms bestudeer. Die uitwendige geslagskenmerke is m.b.v. 'n skandeerelektronmikroskoop en die inwendige geslagstelsels mikrotegnies ondersoek.

Uitwendige geslagsopeninge van die spermatekas, ovidukte en semenvesikels is duidelik sigbaar. Uitwendig is daar ook peniaalsetas, geassosieer met die manlike openinge aangetref. Hierdie setas stem ooreen met die gewone liggaamsetas maar is langer en besit duideliker weerhakies. Hulle kom dikwels in groepe van twee of drie in 'n enkele opening voor. Geen ander sekondêre geslagskenmerke wat met paring geassosieer word, bv. tuberkula pubertatis, is aangetref nie.
\end{abstract}

\section{'n Vergelyking tussen metaalkonsentrasies in die voedsel en weefsel van die skerptandbaber, Clarias gariepinus, en die rooineusonderbek, Labeo rosae, in die Olifantsrivier (NKW)}

\author{
A. Maartens en J.H.J. van Vuren \\ Departement Dierkunde, Randse Afrikaanse Universiteit, Posbus 524, Aucklandpark 2006
}

Die afgelope 20 jaar het die waterlewe in die Olifantsrivier gely onder die nadelige gevolge van onoordeelkundige landboustrategieë, nywerheidsontwikkeling en verstedeliking. Inligting aangaande die moontlike besoedeling van die Olifantsrivier en die vlakke daarvan is tans beperk. In 1990 is ' $n$ moniteringsprogram geloods om 'n begin te maak met
Die vroulike geslagstelsel bestaan uit een paar ovariums en drie paar spermatekas in opeenvolgende segmente, serieel gerangskik. By al die volwasse eksemplare wat geleentheid tot paring gehad het en wat bestudeer is, is sperms in die spermatekas en hulle divertikulums aangetref.

Die manlike geslagstelsel bestaan uit twee paar testes en spermtregters, drie paar semenvesikels, een paar vasa deferentia en een paar prostaatkliere. Die verloop van die vasa deferentia vanaf die spermtregters na die prostaatkliere kan duidelik gevolg word. Sperms is in die spermtregters waargeneem.

Daar is geen verbindings tussen die vroulike en manlike stelsels waargeneem nie en daar bestaan dus geen anatomiese bewyse dat interne selfbevrugting kan plaasvind nie. Die gemodifiseerde peniaalsetas en die teenwoordigheid van sperms in die spermatekas dui op kruisbevrugting. Indien selfbevrugting by die ongepaarde wurms sou voorkom, sou dit moontlik uitwendig in die vormende kokon kon geskied. 'n Ander moontlike strategie wat hierdie wurms sou kon beoefen, is een of ander vorm van partenogenese. Deur diepgaande sitologiese studies wat die bestudering van chromosome en chromosoomgetalle sou moes insluit, sal moontlik lig hierop gewerp kan word. 
Nasionale Krugerwildtuin vloei, versamel. Hierdie weefsel is van die rooineusonderbek, Labeo rosae, en die skerptandbaber, Clarias gariepinus, versamel. Versamelde weefsel is geanaliseer vir konsentrasies van die volgende besoedelingstowwe: yster, mangaan, koper, nikkel, sink, chroom en lood.

Hierdie metale kan langs vier weë deur ' $n$ vis opgeneem word, naamlik deur drinkwater, voedsel, die vel en die kieue. Heath (1987) beweer dat tot $70 \%$ van die geakkumuleerde besoedelingstowwe die liggaam via die voedsel binnegekom het. Die belang van die trofiese vlak waarop ' $n$ vis voed vir die bioakkumulering van swaar metale is ' $\mathrm{n}$ onderwerp waaroor daar tans nog heelwat kontroversie in die literatuur bestaan. Metaalkonsentrasies in die voedsel en weefsel van die baber en die onderbek onderskeidelik is met mekaar vergelyk in 'n poging om meer lig op hierdie vraagstuk te werp.

Vergelykings tussen die maaginhoude van die baber en die bulbusinhoude van die onderbek het deurgaans beduidend hoër Fe-, $\mathrm{Mn}$-, $\mathrm{Cr}$-, $\mathrm{Cu}$ - en $\mathrm{Zn}$-konsentrasies in die voedsel van laasgenoemde getoon vir die maande Februarie, Junie en Augustus 1991. (Die enigste uitsonderings was vir $\mathrm{Cr}$ en Zn tydens Februarie 1991.)

Metale was Junie en Augustus 1991 in die volgende volgordes in die voedsel van die onderskeie spesies teenwoordig:

Labeo rosae: $\quad \mathrm{Fe}>\mathrm{Mn}>\mathrm{Cr}>\mathrm{Zn}>\mathrm{Cu}$

Clarias gariepinus: $\mathrm{Fe}>\mathrm{Cr}>\mathrm{Mn}>\mathrm{Zn}>\mathrm{Cu}$

Verdere maaginhoudidentifikasies het die volgende aan die lig gebring:

Hoë metaalkonsentrasies in anorganiese materiaal en invertebrate.

Lae metaalkonsentrasies in oewerplantvrugte (wildevy) en vis.

Trofiese vlak, asook die seisoen (veral by omnivoriese vis soos die baber) speel dus 'n sleutelrol in die hoeveelheid swaar metale wat die liggaam van die vis via die voedsel binnekom.

Vergelykings tussen metaalkonsentrasies in die weefseltipes van Labeo rosae en Clarias gariepinus vir Junie, Augustus en Oktober 1991 het die volgende aan die lig gebring betreffende die metale Fe, $\mathrm{Mn}, \mathrm{Cu}$ en $\mathrm{Zn}$ :

Konsentrasies in die weefsel van die onderbek hoër as in die van die baber:

Spier: $\mathrm{Fe}, \mathrm{Mn}$,

$\mathrm{Cu}, \mathrm{Zn} \quad$ (Junie, Augustus en Oktober 1991)

Lewer: $\mathrm{Fe}, \mathrm{Cu}$ (Junie, Augustus en Oktober 1991)

Mn, Zn (Junie en Augustus 1991)

Gonades: $\mathrm{Fe}, \mathrm{Cu}$ (Junie, Augustus en Oktober 1991)

$\mathrm{Mn}, \mathrm{Zn} \quad$ (Junie en Augustus 1991)

Kieue: $\mathrm{Fe}, \mathrm{Cu}, \mathrm{Zn}$ (Junie, Augustus en Oktober 1991) Mn (Junie en Augustus 1991)

Konsentrasies in die weef'sel van die baber hoër as in die van die onderbek:
Lewer: $\mathrm{Mn}, \mathrm{Zn}$
(Oktober 1991)
Gonades: $\mathrm{Mn}, \mathrm{Zn}$
(Oktober 1991)
Kieue: $\mathrm{Mn}$
(Oktober 1991)

Die vergelykbare konsentrasies $\mathrm{Fe}, \mathrm{Zn}$ en $\mathrm{Cu}$ wat in die lewer en voedsel van albei spesies voorkom, dui op 'n potensiële gevaar wat hierdie drie metale inhou indien dit in hoë konsentrasies in die voedsel teenwoordig is. $\mathrm{Mn}$ en $\mathrm{Pb}$ is in heelwat hoër konsentrasies in die voedsel as in die lewer van albei spesies teenwoordig en word waarskynlik goed deur die vis gereguleer. Laasgenoemde twee metale sal dus waarskynlik nie so 'n groot bedreiging vir die vis inhou as $\mathrm{Fe}$, $\mathrm{Zn}$, en $\mathrm{Cu}$, as dit in hoë konsentrasies in die voedsel teenwoordig is nie.

Hoër metaalvlakke in die voedsel van Labeo rosae mag dus 'n verklaring bied vir die hoër metaalvlakke in die weetsel var hierdie spesie, wanneer in ag geneem word dat alle ander fisies-chemiese omgewingstoestande vir die twee spesies dieselfde was.

\title{
Die invloed van Schistosoma mansoni op die oorlewing van geografiese stamme van Biomphalaria pfeifferi
}

\author{
K.N. de Kock \\ Departement Dierkunde, Potchefstroomse Universiteit vir CHO, Privaat sak X600I, Potchefstroom 2520
}

Uit die literatuur is dit bekend dat stamme van dieselfde varswaterslakspesie afkomstig uit verskillende geografiese gebiede onder eksperimentele toestande betekenisvol kan verskil in hulle reaksie op eksterne faktore soos byvoorbeeld temperatuur. Die huidige ondersoek is geloods om die verdraagsaamheid van vier verskillende geografiese stamme van die varswaterslak, Biomphalaria pfeifferi, ten opsigte van besmetting met sy verenigbare ingewandsbilharziaparasiet, Schistosoma mansoni, te vergelyk.

Vier parentaalbevolkings ( 100 eksemplare elk) van $B$. pfeifferi afkomstig uit verskillende habitattipes, geleë in twee endemiese bilharziagebiede (Durban en Nelspruit) en in twee nie-endemiese bilharziagebiede (Lichtenburg en Molopo Oog), is in 'n deurvloei-akwariumstelsel in die laboratorium gehuisves. Drie replikaatkohorte van 25 ek- semplare elk (ouderdom vier weke) uit eerstegenerasienakomelinge van elk van die vier parentaalbevolkings, is aan drie mirasidiums per slak van die Nelspruitstam van $S$. mansoni blootgestel. Vir elk van die vier lokaliteite is 'n onbesmette kohort van 25 eksemplare as kontrole aangehou. Vanaf dag 24 na blootstelling is lede van al die kohorte elke derde dag vir die afskeiding van serkarieë ondersoek.

Die eksperimentele opstelling het bestaan uit vlekvrystaalakwariums, elk toegerus met 'n logiese verwerker wat die temperatuur noukeurig op $25 \pm 0,1{ }^{\circ} \mathrm{C}$ beheer het en waarin die kultuurwater aanhoudend gesirkuleer is. Mortaliteite is daagliks aangeteken totdat al die eksemplare van die blootgestelde kohorte dood was. Die daaglikse mortaliteitsyfers is gebruik om die gemiddelde per capita-mortaliteit per week en gemiddelde totale lewensverwagting vir elke 
replikaatkohort te bereken. Die per capita-mortaliteit is ' $n$ parameter wat mortaliteit kwantifiseer en voorspel onder gegewe eksperimentele toestande.

Afskeiding van serkariee het by al die blootgestelde kohorte tussen dag 33 en 36 na blootstelling 'n aanvang geneem. Toe waarnemings op dag 99 gestaak is omdat al die blootgestelde eksemplare dood was, is verliese van nie meer as twee slakke nie by enige van die kontrolekohorte aangeteken.

Volgens Tukey se studentereekstoets vir veranderlike mortaliteit, het die waardes vir gemiddelde per capitamortaliteit per week vir die Durban- en Nelspruitstamme (onderskeidelik 0,34l en 0,333) nie betekenisvol verskil nie. Dit geld ook hierdie waardes vir die stamme van Lichtenburg en Molopo Oog (onderskeidelik 0,136 en 0,127). 'n Betekenisvolle verskil kon wel aangetoon word tussen die waardes vir die eersgenoemde twee lokaliteite aan die eenkant en die laasgenoemde twee lokaliteite aan die anderkant.

Voorspellings vir die gemiddelde sterftes per week vir besmette slakke was ongeveer twee keer hoër (8,53 en 8,32 eksemplare) vir nakomelinge van die twee stamme afkomstig vanaf Durban en Nelspruit, dit wil sê beide endemiese gebiede. Daarenteen was voorspelde waardes vir die totale lewensduur in weke, vir besmette slakke meer as twee keer hoër $(7,34$ en 7,84 weke) vir nakomelinge van die twee stamme afkomstig uit die nie-endemiese bilharziagebiede, Lichtenburg en Molopo Oog.

Hierdie bevindings was ietwat onverwags. Dit sou logies verwag kon word dat slakbevolkings wat reeds vir dekades in die endemiese gebiede aan parasitisme blootgestel was, beter aangepas behoort te wees om die nadelige gevolge van schistosoomparasiete te verdra as dié afkomstig uit nieendemiese bilharziagebiede.

Hierdie resultate maak dit moontlik om die invloed van besmetting met $S$. mansoni op oorlewing van $B$. pfeifferi te $\mathrm{kwantifiseer} \mathrm{en} \mathrm{te} \mathrm{voorspel,} \mathrm{inligting} \mathrm{wat} \mathrm{'n} \mathrm{groot} \mathrm{bate} \mathrm{in} \mathrm{die}$ beplanning van navorsingsprojekte rondom parasiet-tussengasheerwisselwerking kan wees. Verder beklemtoon dit die groot onderlinge variasie tussen bevolkings van dieselfde slakspesie. Daarbenewens bied dit 'n aanvaarbare verklaring vir die teenstrydige bevindings ten opsigte van prepatente mortaliteitskoerse, totale lewensduur en persentasie besmetting na blootstelling aan 'n gegewe getal mirasidiums wat deur verskillende navorsers vir dié bepaalde spesie gerapporteer is. 